${ }^{3}$ Meadows AT, Massori DJ. Fergusson J, Gordon J, Littman P, Moss K. Declines in IQ scores and cognitive dysfunctions in children with acute lymphocytic leukacmia treated with cranial irradiation. Lancet 1981:ii:1015-8.

4 Eiser C. Effects of chronic illness on intellectual development: a comparison of normal children with those treated for childhood leukaemia and solid tumours. Arch Dis Child 1980;55:766-70.
${ }^{5}$ Kramer S. The hazards of therapeutic irradiation of the CNS. Clin Neurosurg 1968;15:301-18.

Correspondence to Dr V Twaddle, Department of Clinical Psychology. Royal Victoria Infirmary, Newcastle upon Tyne NE1 4LP, England.

Received 5 March 1986

\title{
Intralipid microemboli
}

\author{
G HULMAN AND M LEVENE
}

Departments of Histopathology and Neonatal Medicine, Leicester Royal Infirmary

\begin{abstract}
SUMMARY A baby girl died after receiving intravenous Intralipid. At necropsy a pulmonary Intralipid microembolus, unrelated to the cause of death, was found. Serum taken immediately before infusion agglutinated Intralipid. $C$ reactive protein concentration was raised. This supports the theory that $C$ reactive protein may agglutinate Intralipid in vivo, causing embolisation.
\end{abstract}

There have been a number of published reports describing lipid emboli in the tissues of neonates receiving intravenous fat emulsions. ${ }^{1-3}$ Intralipid tends to be agglutinated in vitro (creaming) by sera containing significantly raised concentrations of $\mathrm{C}$ reactive protein ${ }^{4}$ and is also agglutinated by purified
$C$ reactive protein in the presence of calcium ions. It has been postulated that this phenomenon may occur in vivo, resulting in embolisation of Intralipid agglutinates. ${ }^{3}{ }^{4}$ We describe a case that supports this hypothesis.

\section{Case report}

A baby girl was born by elective caesarean section at 34 weeks for breech presentation. She was found to have a tracheo-oesophageal fistula, which was surgically closed the following day. She remained critically ill and four days postoperatively was started on parenteral nutrition, including $10 \%$ Intralipid at an infusion rate of $0.08 \mathrm{~g} /$ hour. Immediately before infusion serum was obtained for estimation of $\mathrm{C}$ reactive protein concentration and a creaming test ${ }^{4}$
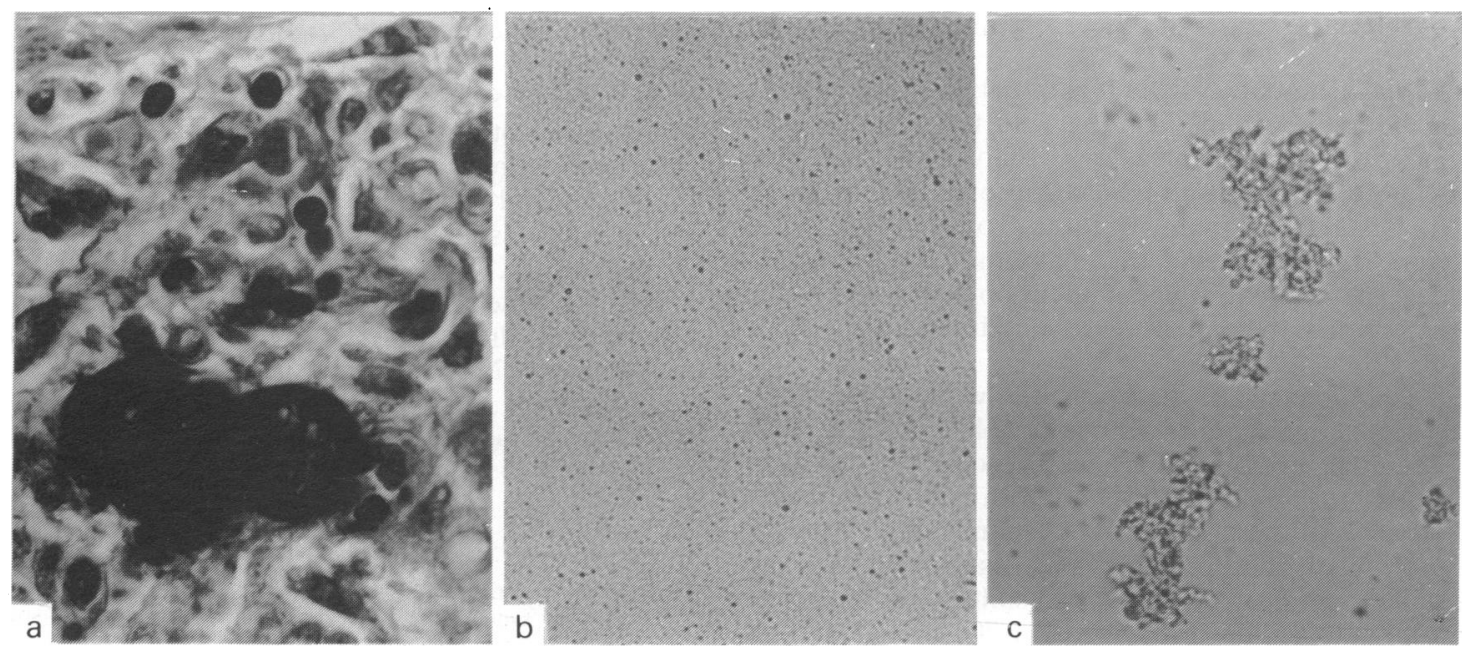

Figure (a) Intralipid microembolus (stained with Sudan black); (b) Normal appearance of Intralipid in serum; (c) Intralipid agglutinated (creamed) by serum. 
performed. The $\mathrm{C}$ reactive protein concentration was high $(119 \mathrm{mg} / \mathrm{l})$, and the creaming test yielded positive results. These results were not available until some days later.

Eight hours after the beginning of infusion of Intralipid the baby suffered a cardiac arrest and died. At necropsy the anastomoses were found to be intact, and the cause of death was cardiac failure due to a large ventriculoseptal defect. Two blocks of each lung were taken and tissue from the kidney also examined. Paraffin sections were stained with Sudan black and examined microscopically for Intralipid microemboli. One microembolus was found in the lung and measured $100 \times 40 \mu \mathrm{m}$ (Fig. (a)). The embolus had the characteristic bubbly appearance described by Barson. ${ }^{1}$ Careful examination of the other lung and kidney sections showed no evidence of fat microemboli.

\section{Discussion}

The baby developed an Intralipid microembolus after only eight hours of infusion of Intralipid at well below the recommended rate. Only one small embolus was seen, but this is perhaps not surprising considering the infant only received $0.64 \mathrm{~g}$ of fat in all. The serum agglutinated Intralipid and contained a high concentration of $\mathrm{C}$ reactive protein at the time of infusion. This supports the hypothesis that microemboli are formed by agglutination of Intralipid in the blood stream by $\mathrm{C}$ reactive protein.

Intralipid normally consists of discrete particles $0 \cdot 1-0.5 \mu \mathrm{m}$ across (Fig. (b)), which when 'creamed' agglutinate into spherical particles $5 \mu \mathrm{m}$ across, which further aggregate into clumps up to $200 \mu \mathrm{m}$ across (Fig. (c)). We suggest that these aggregates may be formed in vivo and are then filtered by the lung and embolise. This would explain the characteristic bubbly appearance on histological examination.

Mughal et al have described fat embolism in a preterm infant receiving Intralipid. ${ }^{5}$ Serum at the time of clinical deterioration agglutinated Intralipid, and the $\mathrm{C}$ reactive protein concentration was raised. Clinical improvement was associated with the absence of agglutination and a decrease in the $\mathrm{C}$ reactive protein concentration. The current case report provides histopathological support to those clinical observations.

Creaming is not a phenomenon peculiar to Intralipid. A recent study has shown that it occurs with many other intravenous fat emulsions. ${ }^{6}$ It is probable, therefore, that patients who embolise Intralipid would embolise other fat emulsions.

In most cases embolisation of fat emulsions may be clinically unimportant, but in some it may exacerbate ventilation perfusion inequalities. The precise pathogenesis of Intralipid embolism is unclear, nor is it known whether the condition is entirely preventable. None the less it may be prudent either to ensure that the $C$ reactive protein concentration is normal (less than $10 \mathrm{mg} / \mathrm{l}$ ) or perform a creaming test to determine which babies may embolise the infused fat emulsion.

\section{References}

1 Barson AJ, Chiswick ML, Doig MC. Fat embolism in infancy after intravenous fat emulsions. Arch Dis Child 1978;55:218-23.

${ }^{2}$ Levene MI, Wigglesworth JS, Desai R. Pulmonary fat accumulation after Intralipid infusion in the preterm infant. Lancet 1980;ii:815-9.

3 Levene MI, Batisti O, Wigglesworth JS, et al. A prospective study of intrapulmonary fat accumulation in the newborn lung following Intralipid infusion. Acta Paediatr Scand 1984;73: 454-60.

${ }^{4}$ Hulman G, Pearson HJ, Fraser I, Bell PRF. Agglutination of Intralipid by sera of acutely ill patients. Lancet 1982;ii:1426-7.

5 Mughal MZ, Robinson MJ, Duckworth W. Neonatal fat embolism and agglutination of Intralipid. Arch Dis Child 1984;59:1098-9.

${ }^{6}$ Lindh A, Johansson B, Lindholm M, Rossner S. Agglutinate formation in serum samples mixed with intravenous fat emulsions. Crit Care Med 1985;13:151-4.

Correspondence to Dr G Hulman, Department of Histopathology, St George's Hospital Medical School, Cranmer Terrace, Tooting, London SW17 0RE.

Received 25 February 1986 